\title{
New observations on the spermotoxic properties of normal rabbit serum
}

\author{
R. J. T. Hancock* \\ Institute of Animal Genetics, University of Edinburgh, \\ West Mains Road, Edinburgh EH9 $3 J N$, U.K.
}

'Natural' antibodies to spermatozoa have been detected in rabbit serum by a variety of techniques, summarized by Edwards (1967), and it would seem reasonable to attribute the spermotoxicity of fresh rabbit serum, described by Walsh (1925) and Chang (1947), to the activity of these antibodies in conjunction with serum complement. There have, however, been observations which do not support this hypothesis. Edwards (1960) found that the spermotoxic activity of rabbit serum, which disappears when the complement in the serum is inactivated by heating, was not restored by the addition of fresh complement (diluted guinea-pig serum). Similarly, in guinea-pigs, Spooner (1964) was unable to restore the sperm-immobilizing activity of heated guinea-pig serum by the addition of complement.

In contrast to these observations, I have found that heated rabbit serum showed pronounced spermotoxicity when used in conjunction with guinea-pig serum, in an assay based on one used by Menge (1970) to assay induced antibodies to rabbit spermatozoa.

Samples $(0.25 \mathrm{ml})$ of diluted, heat-inactivated rabbit serum were incubated with $0.05 \mathrm{ml}$ of a $\frac{1}{10}$ dilution of guinea-pig serum (Wellcome Reagents Ltd, Beckenham, Kent) and $0.05 \mathrm{ml}$ of a suspension of ejaculated spermatozoa $\left(30 \times 10^{6} / \mathrm{ml}\right)$ collected, with an artificial vagina, from bucks selected for the high percentages of motile spermatozoa in their ejaculates. The ejaculates were diluted about 15 times, and centrifuged at $650 \mathrm{~g}$ for 5-10 min. The supernatant was discarded and the spermatozoa resuspended in fresh diluent (Dulbecco A: Oxoid). Tubes containing $0.25 \mathrm{ml}$ diluent $+0.05 \mathrm{ml}$ complement and tubes containing $0.25 \mathrm{ml}$ serum $+0.05 \mathrm{ml}$ heat-inactivated complement were included as controls. The tubes were incubated at $37^{\circ} \mathrm{C}$ for $1 \mathrm{hr}$ and drops of each suspension were examined microscopically to determine the effects of the treatments on sperm motility. Nigrosin-eosin smears (Hancock, 1951) were made to determine the degree to which spermatozoa could exclude eosin. Single drops of sperm-serum suspension were mixed with equal volumes of nigrosin-eosin stain

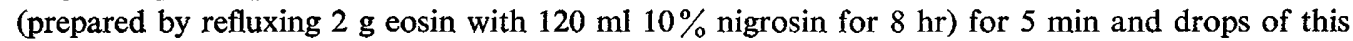
suspension smeared. The spermatozoa were examined under oil-immersion.

The percentage of spermatozoa that were motile or able to exclude eosin was greatly decreased after incubation in serum+unheated complement compared with spermatozoa in the control tubes. Individual ejaculates varied in their sensitivity to a given batch of serum, but dilutions of serum from $\frac{1}{10}$ to $\frac{1}{40}$ usually reduced the percentages of motile spermatozoa to less than half those in the control tubes.

Using a procedure similar to that described by Edwards (1960), i.e. incubating $0 \cdot 1 \mathrm{ml}$ volumes of heated rabbit serum, complement and sperm suspension $\left(20 \times 10^{6} / \mathrm{ml}\right)$ for $1 \mathrm{hr}$ with Dulbecco A (Oxoid) as diluent, higher percentages of eosin-stainable spermatozoa were found in suspensions containing rabbit serum+complement than in control tubes. This procedure was also tried with various sources of complement-freeze-dried guinea-pig serum supplied by Wellcome Reagents, guinea-pig serum which had been stored frozen at $-80^{\circ} \mathrm{C}$, or guinea-pig serum which had been absorbed with ejaculated rabbit spermatozoa in the absence of $\mathrm{Ca}^{++}$and $\mathrm{Mg}^{++}$ions (Boyse, Hubbard, Stockert \& Lamm, 1970). Spermotoxicity of rabbit serum was obtained with all these procedures, but they were not used routinely. Spermotoxicity was observed in all sera tested from 2 male and 17 female rabbits.

I can only speculate about the reasons for the differences between my observations and those of Edwards (1960). These may have been due to slight differences in the procedures used, or differences

* Present address: Reproductive Immunology Group, Department of Pathology, University of Bristol, Bristol BS8 1TD, U.K. 
Table 1. Percentages of unstained ('live') spermatozoa found when samples of spermatozoa from different ejaculates were incubated with samples of guinea-pig serum from different batches and rabbit serum or Dulbecco $A$

\begin{tabular}{|c|c|c|c|c|}
\hline Experiment & Guinea-pig serum & Addition & $\begin{array}{c}\text { Live spermatozoa } \\
(\%)\end{array}$ & $\begin{array}{c}95 \% \text { confidence } \\
\text { limits }(\%)\end{array}$ \\
\hline \multirow[t]{4}{*}{$I^{*}$} & Batch 5 & Rabbit serum & 64 & $50-77$ \\
\hline & & Dulbecco A & 64 & $50-77$ \\
\hline & Batch 6 & Rabbit serum & 24 & $13-38$ \\
\hline & & Dulbecco A & 74 & $59-85$ \\
\hline \multirow[t]{6}{*}{$\mathrm{II} \dagger$} & Batch 7 & Rabbit serum & 16 & $7-29$ \\
\hline & 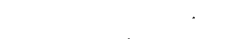 & Dulbecco A & 62 & $47-75$ \\
\hline & Batch 5 & Rabbit serum & 78 & $64-88$ \\
\hline & & Dulbecco A & 70 & $56-82$ \\
\hline & Batch 1 & Rabbit serum & 52 & $37-66$ \\
\hline & & Dulbecco A & 60 & $45-73$ \\
\hline \multirow[t]{6}{*}{ III } & Batch 4 & Rabbit serum & 8 & $2-19$ \\
\hline & & Dulbecco A & 78 & $64-88$ \\
\hline & Batch 3 & Rabbit serum & 14 & $6-27$ \\
\hline & & Dulbecco A & 44 & $30-59$ \\
\hline & Batch 2 & Rabbit serum & 82 & $69-91$ \\
\hline & & Dulbecco A & 74 & $59-85$ \\
\hline
\end{tabular}

* Sperm suspension $\left(30 \times 10^{6}\right.$ sperm. $\left./ \mathrm{ml}\right), 0.05 \mathrm{ml}$; guinea-pig serum $(1 / 10), 0.05 \mathrm{ml}$; rabbit serum $(1 / 40), 0.25 \mathrm{ml}$; Dulbecco A, $0.25 \mathrm{ml}$.

† Sperm suspension $\left(20 \times 10^{6}\right.$ sperm. $\left./ \mathrm{ml}\right), 0.1 \mathrm{ml}$; guinea-pig serum $(1 / 15), 0.1 \mathrm{ml}$; rabbit serum $(1 / 10), 0.1 \mathrm{ml}$; Dulbecco A, $0 \cdot 1 \mathrm{ml}$.

$\ddagger$ Sperm suspension $\left(30 \times 10^{6}\right.$ sperm. $\left./ \mathrm{ml}\right), 0.05 \mathrm{ml}$; guinea-pig serum $(1 / 2.5), 0.05 \mathrm{ml}$; rabbit serum $(1 / 10), 0.25$ $\mathrm{ml}$; Dulbecco A, $0.25 \mathrm{ml}$.

in the properties of the rabbit sera or complement sources. The effects described could be more readily demonstrated with some complement sources than with others (see Table 1). Where comparisons were made, the more satisfactory sources had higher haemolytic complement titres.

The spermotoxic activity of rabbit serum reported here, which is similar to the activity of mouse serum reported by Johnson \& Edidin (1972), could be due to the activity of naturally occurring antisperm immunoglobulins, but the molecular basis for the phenomenon has not been fully worked out as only preliminary attempts have been made to isolate the spermotoxic activity of rabbit serum in a purified fraction. IgG fractions prepared by ammonium sulphate precipitation (Campbell, Garvey, Cremer \& Sussdorf, 1964), absorption with DEAE Sephadex (Webb, 1972) and Sephadex gel filtration, all contained spermotoxic activity when tested using the first assay described in this communication, but the yield of activity was low, and it was not possible to conclude that the spermotoxicity of rabbit serum in this assay could be entirely attributed to IgG.

This work was supported by a grant from the Ford Foundation. I thank Dr R. A. Beatty for his supervision, and Dr D. Pepper of the Regional Blood Transfusion Service for giving me advice on the purification of serum fractions, for carrying out the gel filtration, and giving me the DEAE-Sephadex used to purify IgG.

\section{References}

Boyse, E.A., Hubbard, L., Stockert, E. \& Lamm, M.E. (1970) Improved complementation in the cytotoxic test. Transplantation 10, 446-449.

Campbell, D.A., Garvey, J.S., Cremer, M.E. \& SussDoRF, D.H. (1964) Methods in Immunology. W. A. Benjamin, New York and Amsterdam.

Chang, M.C. (1947) The effects of serum on spermatozoa. J. gen. Physiol. 30, 321-335.

EDWARDS, R.G. (1960) Complement fixing activity of normal rabbit serum with rabbit sperm and seminal plasma. J. Reprod. Fert. 1, 268-282.
EDWARDS, R.G. (1967) Antigenicity of spermatozoa with respect to fertility and infertility. Proc. Internat. Symp. The Immunology of Spermatozoa and Fertilisation, Varna, 1967, pp. 27-34. Eds K. Bratanov, V. H. Vulchanov, V. Dikov, K. Dokov \& B. Somley. Bulgarian Academy of Sciences Press.

HANCOCK, J.L. (1951) A staining technique for the study of temperature-shock in semen. Nature, Lond. 167, 323-324.

Johnson, M.H. \& EDIdIN, M. (1972) H-2 antigens on mouse spermatozoa. Transplantation 14, 781-786. 
Menge, A.C. (1970) Use of polynucleotides with seminal antigens to induce isoantibodies and infertility in rabbits. Proc. Soc. exp. Biol. Med. 135, 108-112.

SPOONER, R.L. (1964) Cytolytic activity of the serum of normal male animals against their own testicular cells. Nature, Lond. 202, 915-916.
WALSH, L.S. (1925) Natural auto- and homo-spermotoxins in guinea pig serum. J. Immun. 10, 803809.

WEBB, A.J. (1972) A 30-minute method for isolation of IgG from human serum. Vox Sang. 23, 279290.

Received 29 July 1975 